\title{
Loftslagsbreytingar og heilsufar
}

Frá síðasta fjórðungi liðinnar aldar hefur hlýnað viðstöðulítið víðast hvar á yfirborði jarðar. Afleiðingar hlýnunarinnar eru pegar farnar að koma fram í bráðnun jökla, hækkandi sjávarstöðu, aukinni tíðni óveðra, bæði hitabylgna og aftakaúrkomu. Bein áhrif á lífríki eru nú pegar nokkur, og gætir breytinga á útbreiðslu dýra- og plöntutegunda, tíma laufgunar trjáa auk pess sem árstíðabundin hegðan dýrategunda (koma farfugla, ganga fiskistofna) hefur breyst með áhrifum á stofnstærð og víxlverkun við aðrar tegundir.

Mismunandi er hversu berskjölduð pjóðfélög eru fyrir áhrifum loftslagsbreytinga og ræðst pað af styrk innviða, atvinnuháttum, stjórnarháttum og öðrum pjóðfélagslegum páttum, - en ekki bara af umfangi loftslagsbreytinga.

Ofangreind upptalning ætti ekki að koma á óvart, pví búið var að spá pessari próun fyrir nokkru síðan. Spár um hlýnun jarðar eru nokkurra áratuga gamlar, og upptalning á líklegum afleiðingum fyrir vistkerfi og félagskerfi margar frá pví fyrir síðustu aldamót.

Í skýrslu vísindanefndar um loftslagsbreytingar sem kom út síðastliðið vor ${ }^{1}$ er farið yfir pekkingu vísinda á loftslagsbreytingum og afleiðingum peirra á Íslandi. Meðal annars kemur fram að afleiðingar hlýnunar síðustu áratuga hér á landi séu auðsæjar og víðfeðmar, - birtast í pynningu jökla, grænkun lands og breytingum á komutíma farfugla og tegundasamsetningu. Skýrslan ræðir einnig væntanlegar loftslagsbreytingar á komandi öld, en á Íslandi verður hlýnun að jafnaði nærri hnattrænni hlýnun, pó óvissa um próun á hafsvæðunum umhverfis landið sé veruleg.

Hversu mikið hlýnar hnattrænt fer eftir losun gróðurhúsalofttegunda, verði hún í takt við ákvæði samkomulagsins sem náđist í París 2015 verður hnattræn hlýnun innan við $2^{\circ} \mathrm{C}$.

Í skýrslu vísindanefndar frá árinu $2008^{2}$ er stuttlega fjallað um hvaða áhrif líklegt sé að loftslagsbreytingar hafi á heilsufar á hnattræna vísu og er par byggt á úttekt milliríkjanefndar Sameinuðu pjóðanna (IPCC) frá 2007. Par kemur fram að líklega muni loftslagsbreytingar hafa áhrif á heilsu milljóna manna, einkum hópa sem hafa litla getu til aðlögunar. Meðal helstu áhyggjuefna voru vannæring og sjúkdómar henni tengdir, niðurgangssóttir og öndunarfærasjúkdómar, slys og sjúkdómar tengdir náttúruhamförum, hitabylgjum, fárviðri og flóðum og að lokum var bent á að smitleiðir kynnu að breytast og smitberar að nema ný lönd.

Skýrslan ræddi einnig stöðu pekkingar á heilsufarsáhrifum loftslagsbreytinga á Íslandi, og bent á að helstu áhættupættir væru taldir smitsjúkdómar og aukin tíðni ofnæmissjúkdóma, en síðari pátturinn tengdist breytingum á gróðurfari. Sjúkdómar á borð við veiruheilahimnubólgu og Borreliosis sem tengjast smámaurnum Ixodes ricinus hafa breiðst út í Norð- ur Evrópu, og nái maurinn landfestu kynni slíkt að gerast hér. Hlýnun ein og sér nægir pó ekki til pví hin fábreytta fána villtra spendýra á Íslandi og lítill péttleiki peirra vinnur gegn viðkomu maursins sem er háđur slíkum millihýslum.

Ný skýrsla vísindanefndar bætir pví miður ekki miklu við umfjöllun um möguleg áhrif loftslagsbreytinga á heilsufar á Íslandi. Pó er rætt ítarlegar um hlýnun og frjókornatímabil, og hugsanlega tengingu hlýnunar og aukinnar tíðni myglu innandyra vegna meiri loftraka, en samkvæmt erlendum rannsóknum getur tíðni myglu innandyra á köldum svæðum aukist um $5-10 \%$ við hlýnun. Í niðurlagi umfjöllunar um loftslagsbreytingar og heilsufar á Íslandi er endurtekin samantekt fyrri skýrslna um að miðað við prótt heilbrigðiskerfisins bendi ekkert til annars en að pað muni ráða við pað álag sem breytingunum kann að fylgja.

Ástæða pess að ný skýrsla vísindanefndar bætir svo litlu við eldri umfjöllun um heilsufarsáhrif hér á landi er sú að petta umfjöllunarefni hefur ekki haft mikið vægi í heilbrigðisrannsóknum á Íslandi. Hlutverk vísindanefndar er að taka saman fyrirliggjandi upplýsingar og ástand pekkingar, nefndin stundar ekki sjálfstæðar rannsóknir. Verulega parf að bæta við rannsóknir um petta efni á næstu árum svo betur megi tryggja að nauðsynleg pekking verði til staðar.

Sagt hefur verið að fyrir heimsbyggðina séu einungis prír kostir í boði: Að draga úr losun, aðlagast breytingum eða pjást. $^{3}$ Umfjöllun um loftslagsbreytingar beinir athyglinni oft að síðasttalda atriðinu og neikvæðum afleiðingum breytinganna. Petta mátti greinilega sjá í haust sem leið, pegar milliríkjanefndin gaf út skýrslu um hvaða möguleikar væru á pví að takmarka hlýnun jarðar við $1,5^{\circ} \mathrm{C}$ í stað $2^{\circ} \mathrm{C}$. Prátt fyrir pá niðurstöðu skýrslunnar að með eindregnum aðgerðum væri mögulegt að ná pessu marki féll sú niðurstaða nokkuð í skugga pess að í skýrslunni var einnig lýst muninum á áhrifum $1,5^{\circ} \mathrm{C}$ og $2^{\circ} \mathrm{C}$ hlýnunar, en tjónið vex með hlýnun.

Pað er óparfi að láta pað tjón sem loftslagsbreytingar geta valdið draga athyglina frá pví verkefni sem við stöndum frammi fyrir. Við purfum að draga úr losun gróðurhúsalofttegunda eins hratt og mikið og unnt er, og vinna að pví að styrkja innviði svo aðlagast megi peim afleiðingum loftslagsbreytinga sem óumflýjanlegar eru. Á pann hátt má draga úr peim skakkaföllum sem loftslagsbreytingar hafa í för með sér.

\section{Heimildir}

1. Björnsson H, Sigurðsson BD, Davíðsdóttir B, Ólafsson J, Ástpórsson ÓS, Ólafsdóttir S, et al. Loftslagsbreytingar og áhrif peirra á Íslandi - Skýrsla vísindanefndar um loftslagsbreytingar. Veðurstofa Íslands 2018.

2. Björnsson H, Sveinbjörnsdóttir ÁE, Daníelsdóttir AK, Snorrason Á, Sigurðsson BD, Sveinbjörnsson E, et al. Hnattrænar loftslagsbreytingar og áhrif peirra á Íslandi - Skýrsla vísindanefndar um loftslagsbreytingar. Umhverfisráðuneytið 2008.

3. Holdren J. Science and Technology for Sustainable Well-Being. Science 2008; 319: 424-34.



Halldór Björnsson

veðurfræðingur á

Veðurstofu Íslands

halldor@vedur.is

\section{Climate change and health}

Dr. Halldór Björnsson, Head of the Atmospheric Research Group, Icelandic Meteorological Office doi.org/10.17992//bl.2018.12.205 